\title{
Bone Marrow Donation from the Perspective of Sibling Donors ${ }^{1}$
}

\author{
Érika Arantes de Oliveira-Cardoso² \\ Manoel Antônio dos Santos ${ }^{3}$ \\ Ana Paula Mastropietro ${ }^{4}$ \\ Júlio César Voltarelli ${ }^{5}$
}

This study aimed to characterize the sociodemographic profile of sibling bone marrow donors and to describe how they perceive the donation. This was a descriptive, exploratory and longitudinal study. Participants were 20 related bone marrow donors, between 18 and 42 years of age (mean $=30.5$ years, $s d=7.47$ ). Interviews were held before and immediately after the donation. Sociodemographic data were subject to descriptive statistical analysis and qualitative data to categorical content analysis. In the interviews held before the donation, stressor events were the sibling's disease and treatment and the responsibility of being the donors. During the interviews after the donation, the following were mentioned: anxiety on the day before and on the day of the donation, pain the following day, and acknowledgement of the health team's support as a facilitator of the donation process. In view of the findings, it is important for the team to outline intervention strategies to meet to the donors' specific needs.

Descriptors: Tissue Donors; Family; Bone Marrow Transplantation; Mental Health.

\footnotetext{
${ }^{1}$ Paper extracted from Master's Thesis "Repercussões psicológicas da doação da medula óssea no doador relacionado", presented to Faculdade de Filosofia Ciências e Letras de Ribeirão Preto, Universidade de São Paulo, SP, Brazil. Supported by FAPESP, process \# 2000/01464-0.

2 Psychologist, Ph.D. in Psychology, Faculdade de Filosofia Ciências e Letras de Ribeirão Preto, Universidade de São Paulo, SP, Brazil. E-mail: erikaao@ffclrp.usp.br.

${ }^{3}$ Psychologist, Ph.D. in Psychology, Professor, Faculdade de Filosofia Ciências e Letras de Ribeirão Preto, Universidade de São Paulo, SP, Brazil. E-mail: masantos@ffclrp.usp.br.

${ }^{4}$ Occupational Therapist, Ph.D. in Psychology, Hospital das Clínicas, Faculdade de Medicina de Ribeirão Preto, Universidade de São Paulo, SP, Brazil. E-mail: anapmastro@bol.com.br.

${ }^{5}$ Physician, Ph.D. in Medical Clinic, Full Professor, Faculdade de Medicina de Ribeirão Preto, Universidade de São Paulo, SP, Brazil. E-mail: jcvoltar@fmrp.usp.br.
}

Corresponding Author:

Érika Arantes de Oliveira-Cardoso

Universidade de São Paulo. Faculdade de Filosofia, Ciências e Letras de Ribeirão Preto.

Departamento de Psicologia e Educação.

Av. dos Bandeirantes, 3900

Bairro Monte Alegre

CEP: 14040-901 Ribeirão Preto, SP, Brasi

E-mail: erikaao@ffclrp.usp.br 


\section{Doação de medula óssea na perspectiva de irmãos doadores}

Este estudo objetivou caracterizar o perfil sociodemográfico e descrever a percepção de irmãos doadores de medula óssea acerca da doação. Trata-se de estudo descritivo, exploratório e com recorte longitudinal. Participaram 20 doadores relacionados de medula óssea, com idade entre 18 e 42 anos (média=30,5 anos, dp=7,47). Foram utilizadas entrevistas, aplicadas antes e imediatamente após a doação. Foi realizada análise estatística descritiva dos dados sociodemográficos e análise de conteúdo categorial dos dados qualitativos. Nas entrevistas anteriores à doação, apareceram como eventos estressores o adoecimento e o tratamento do irmão e a responsabilidade de serem os doadores. No período posterior à doação, foi relatada ansiedade na véspera e no dia da doação, dor no dia seguinte, e o reconhecimento do apoio da equipe como elemento facilitador do processo de doação. Frente aos achados é interessante que a equipe possa traçar estratégias de intervenção que permitam atender as necessidades específicas dos doadores.

Descritores: Doadores de Tecidos; Família; Transplante de Medula Óssea; Saúde Mental.

\section{Donación de médula ósea en la perspectiva de hermanos donadores}

Este estudio objetivó caracterizar el perfil socio demográfico y describir la percepción, de hermanos donadores de médula ósea, acerca de la donación. Se trata de estudio descriptivo, exploratorio y con recorte longitudinal. Participaron 20 donadoresrelacionados de médula ósea, con edades entre 18 y 42 años (promedio=30,5 años, de $=7,47$ ). Fueron utilizadas entrevistas, aplicadas antes e inmediatamente después de la donación. Fue realizado un análisis estadístico descriptivo de los datos socio demográficos y análisis de contenido categorial de los datos cualitativos. En las entrevistas antes de la donación aparecieron como eventos causantes de estrés: el enfermarse, el tratamiento del hermano y la responsabilidad de ser los donadores. En el período posterior a la donación fue relatada ansiedad (en la víspera y en el día de la donación), dolor en el día siguiente, y reconocimiento del apoyo del equipo como elemento facilitador del proceso de donación. Frente a lo encontrado, se recomienda que el equipo planifique estrategias de intervención que permitan atender las necesidades específicas de los donadores.

Descriptores: Donadores de Tejido; Família; Trasplante de Medula Ósea; Salud Mental.

\section{Introduction}

Bone Marrow Transplantation (BMT) is becoming an effective alternative treatment for potentially fatal illnesses ${ }^{(1)}$, the diagnoses of which generate psychological impact for the patient and their family unit ${ }^{(2)}$. Families who are confronted with this challenge are generally faced with the disruption of quotidian life, as it was prior to diagnosis. Coupled with this grief, the families are forced to face the destruction of the family myth that the fatal diseases only happen to others ${ }^{(3)}$.

The diagnosis introduces a moment of crisis, to the extent that a new conflict sets in, generating unrest and insecurity in both the patient and the family: whether or not to undergo BMT? This questioning takes place, mainly, due to the peculiarities of the therapy - the transplant is seen as a savior-treatment and at the same time, a threatening-treatment ${ }^{(4)}$ because of the associated risks. Once the option for transplant has been defined, the search begins for the identification of a donor of compatible bone marrow, which can be obtained from the family nucleus (related donor) or from donating volunteers (unrelated donors). In general, the donation is made by a relative, frequently a sibling, 
chosen through a prior examination for the detection of compatibility ${ }^{(1)}$. Thus, a new character is introduced in the scene: the bone marrow donor.

The donor is hospitalized the day before the procedure and will remain hospitalized for two to three days. In most cases, to achieve the aspiration of the marrow the donor receives general or spinal anesthesia. The collection is performed by bilateral access of the posterior iliac crests through a calibrated needle performing punctures in iliac bone. The total volume of marrow removed, on average, is close to a liter. After completion of the procedure, the donor often requires an autotransfusion of blood. They will be released the day after the donation and will have recovered in approximately 20 days. Despite the fact that it is an invasive procedure, it normally leaves no physical sequelae(1).

In related donation, what motivates the donor is the fact that the individual is situated, potentially, as the savior of the life of a family member, being very difficult to refuse the gift in these circumstances. The responsibility delegated by the family in relation to the survival of their sibling, often, becomes an oppressive emotional overload, which may trigger a significant amount of anxiety ${ }^{(5)}$.

A study was conducted with the aim of evaluating the experience of donating bone marrow, for related and unrelated donors, before and after the collection procedure $^{(6)}$. The results indicated that in the predonation period, the related donors endorsed more items of the Beck Depression Inventory (BDI) and after the donation, reported a sensation of pain greater than the unrelated donors. These results suggest the importance of psychological factors in bone marrow donation.

Later the same author and his collaborators(7) conducted a study aiming to identify the changes occurring after the donation for related donors. Through analysis of the BDI, they found that approximately six months after the donation, the donors whose recipients died had a higher rate of depressive symptoms than their counterparts, whose siblings survived. This result shows that the emotional state of the related donor is associated with patient survival(8). A previous study ${ }^{(9)}$ had already demonstrated that the depreciation of the quality of life and physical health of the recipient causes an adverse impact on the life of the related donor. It is confirmed, therefore, that the physical conditions of the recipient are associated with the emotional reactions to the donor ${ }^{(4)}$.
In relation to the experience of donating bone marrow, where literature is still very restricted, it is perceived that the act of donating brings diverse psychological implications for donors: before the donation in the form of anxiety ${ }^{(10-11)}$, immediately after the process, due to the influence of psychological factors and years elapsed, as changes arising in the quality of life ${ }^{(12)}$.

There is a shortage of studies dedicated to evaluating the experience and subjective implications of donating bone marrow for the related donor. This study aims to reduce this gap. It appears that, in publications, attention is focused more on comprehending the process of bone marrow transplantation for patients ${ }^{(13)}$, or other members of the family nucleus(2). The issue of organ donation appears especially in postmortem donations, following the perceptions of family members ${ }^{(14)}$ and professionals $^{(15)}$.

In this context, this study aimed to characterize the sociodemographic profile of participants and to comprehend the perception of sibling bone marrow donors regarding the donation, identifying the motives, feelings and expectations related to the process.

\section{Method}

This was a descriptive, exploratory, longitudinal study. It can be characterized as clinical research since the research problem emerges from the practical experience of the researcher(16).

\section{Participants}

Study participants were 20 bone marrow donors, all siblings of patients in the BMT Unit of the Clinical Hospital of the Faculty of Medicine of Ribeirão Preto. The participants were recruited from a consecutive series of donors in the BMTU, following the criteria of non-probabilistic convenience sampling. The following inclusion criteria were adopted: participants over 18 years of age, of both sexes, related bone marrow donors, who agreed to participate in the research. Exclusion criteria were: history of psychiatric disorders and/or organic frailty, or any other physical or intellectual condition that could impair the comprehension of the task.

The ages of participants ranged from 18 to 42 years, with a mean of 30.5 years and standard deviation of 7.47. As shown in Table 1, the sample was well distributed in relation to gender, 11 men and nine women, $60 \%$ were married. There was a low education level: 55\% had not completed elementary education, 
and a diversity of occupations, with a predominance of activities that require low professional qualifications and provide a low income: $70 \%$ of participants received one to two minimum monthly wages. The siblings were suffering from severe hematological diseases, most were diagnosed with chronic myeloid leukemia.

Table 1 - Sociodemographic characterization of the sample of bone marrow donors based on age, gender, marital status, educational level, family income, occupation and diagnosis of sibling $(n=20)$

\begin{tabular}{|c|c|c|}
\hline Characteristic & $\mathrm{n}$ & $\%$ \\
\hline \multicolumn{3}{|l|}{ Age } \\
\hline $18-30$ & 8 & 40 \\
\hline $31-42$ & 12 & 60 \\
\hline \multicolumn{3}{|l|}{ Gender } \\
\hline Male & 11 & 55 \\
\hline Female & 9 & 45 \\
\hline \multicolumn{3}{|l|}{ Marital status } \\
\hline Married or with partner & 12 & 60 \\
\hline Single or separated & 8 & 40 \\
\hline \multicolumn{3}{|l|}{ Education } \\
\hline Incomplete elementary education & 11 & 55 \\
\hline Complete elementary education & 4 & 20 \\
\hline Incomplete high school & 4 & 20 \\
\hline Complete high school & 1 & 5 \\
\hline \multicolumn{3}{|l|}{ Occupation } \\
\hline housewife & 5 & 25 \\
\hline salesperson & 3 & 15 \\
\hline construction worker & 3 & 15 \\
\hline unemployed & 2 & 10 \\
\hline student & 2 & 10 \\
\hline HGV driver & 2 & 10 \\
\hline farmer & 2 & 10 \\
\hline waiter & 1 & 5 \\
\hline \multicolumn{3}{|l|}{ Household income (Minimum Wage) } \\
\hline Less than $1 \mathrm{MW}$ & 4 & 20 \\
\hline 1 to $2 \mathrm{MW}$ & 14 & 70 \\
\hline More than 2 up to $5 \mathrm{MW}$ & 2 & 10 \\
\hline \multicolumn{3}{|l|}{ Diagnosis of sibling } \\
\hline Chronic Myeloid Leukemia & 11 & 55 \\
\hline Acute Myeloid Leukemia & 4 & 20 \\
\hline Severe Aplastic Anemia & 3 & 15 \\
\hline Myelodysplastic Syndrome & 2 & 10 \\
\hline
\end{tabular}

\section{Ethical considerations}

Data collection occurred after the project was approved by the Research Ethics Committee of HCFMRPUSP (process no 7617/99). The participants were informed in advance of the objectives of the study and the conditions of professional confidentiality, and those who agreed to cooperate freely signed the free prior informed consent form. It was emphasized that refusal to participate in the study would not cause any prejudice in the attendance of the participant or their sibling in the hospital institution.

\section{Instruments}

A script for the semi-structured interview was used as the instrument. The interview is one of the principal means available to the researcher for data collection, since it values the conscious and active presence of the researcher and offers the possibility for the interviewee to achieve freedom and spontaneity in their responses ${ }^{(17)}$.

In the pre-donation stage the script of the interview was designed to collect information about personal background, family history, current condition of life, perceptions about the illness of the sibling, the transplantation of bone marrow and bone marrow donation, motivation and expectations associated with the donation, as well as the expectations and future projects of donors. The post-donation interview was aimed at investigating the awareness of donors about the donation process: memories of what happened immediately before the donation, of the marrow aspiration, and of the moment immediately after that.

\section{Data collection}

Data collection was divided into two periods: before and immediately after donation. The interviews were conducted in a closed environment and recorded in audio, with the consent of the participant. They followed a previously established script and were applied individually. The mean duration of the interviews was one hour.

\section{Data analysis}

Data regarding sociodemographic characteristics of the sample donors were subjected to descriptive analysis, with measurements of frequency, dispersion and central tendency, using the program SPSS, version 13.0.

The interviews were analyzed qualitatively. The procedures for the analysis of categorical content ${ }^{(18)}$ were employed. The recordings were transcribed verbatim and literally, constituting the corpus of analysis. Next, a horizontal reading of the answers to the questions was carried out. The reports were categorized by content analysis, followed the steps: (1) Pre-analysis: 
organization of material and systematization of ideas, (2) analytical description: categorization of data and (3) referential interpretation: processing and interpretation of data. After these steps segments of speech were selected to illustrate the subcategories constructed.

\section{Results}

The categories encountered were systematized in Figure 1. Attention was given to subcategories found within each category, which appear highlighted in bold.

\begin{tabular}{|c|l|l|}
\hline \multicolumn{2}{|c|}{ Category } & \\
\hline 1 & Life before the illness of the sibling & $\begin{array}{l}\text { This category includes family nucleus relationships, especially with the sibling who was ill, the } \\
\text { constitution of their own family, work and study. }\end{array}$ \\
\hline 2 & Changes resulting from the illness of the sibling & $\begin{array}{l}\text { This category concerns the reaction to the diagnosis, the decision to perform the transplant } \\
\text { and the resolution to donate bone marrow. }\end{array}$ \\
\hline 3 & Experiencing the donation of bone marrow & $\begin{array}{l}\text { This category concerns the feelings experienced the day before, immediately before and after } \\
\text { marrow donation. }\end{array}$ \\
\hline
\end{tabular}

Figure 1 - Categories constructed from the analysis of the discourses of related bone marrow donors, in interviews pre and post-bone marrow donation. $(n=20)$

\section{Life before the sibling's illness}

Regarding living conditions, it was found that 18 donors had been born in small towns and had left their hometowns in search of better working conditions. The families of origin were large; half of the donors had more than six siblings. There were 14 children, and my father and mother. At 18 years old we moved to a larger city (Male, 36 years, separated).

Due to the large number of people in the family, 16 donors said they had to work from infancy to help their parents financially. This need for early labor was used to justify the abandonment of studies. In fact, 11 donors have not completed elementary school. I could not study much because of work. I studied until the fifth grade only. It was a life of suffering (Male, 40 years, married).

The relationship with the family nucleus was considered good by 17 participants. I've always been close to my parents. I fought with my brothers, but soon we were together again. (Male, 40 years, married). Difficulties in the relationship with the mother appear in the speech of 17 participants. It is highlighted that, from very early in life, the family burden was a marked characteristic of the family organization. After she was widowed, she was strict. I think she was afraid of bringing up bad people and it ended up driving us away from her (Female, 18 years, married).

Marriage was considered early for half of the donors, who said that they were not prepared for married life and this eventually led to them moving away from the family nucleus after marriage. I ran away with him when I was 13 years old. I was very young, I was living my first love. Then I walked away from everyone, each one will take care of their family (Female, 34 years, married).
In general the relationship with the affected sibling was considered good, with 12 donors believing they were always closer to that sibling and four claiming they had a good relationship and have become closer after the discovery that they would be donors. We were already close. But after I found out we continued to be brothers, but it seems it is more... (Male, 40 years, married). In contrast four of the donors said they had difficulty in the relationship with their sick sibling and that this framework had not changed after the illness and the donation. Our relationship continues to be temperamental. He is bad and has not changed anything. What has changed is that now I know he depends on me (Female, 33 years, legally separated).

\section{Changes resulting from the illness of the sibling}

The most common reactions to the diagnosis reported by participants were "surprise" and "despair", verbalized by all the donors, who claimed that the discovery of the disease was an unexpected event. In fact, 18 donors had not noticed anything wrong with the sibling's health before the diagnosis of disease. I had not noticed anything wrong with him. He began to sweat a lot and went to see a doctor. It was all very fast (Female, 31 years, married).

Faced with the impact of the diagnosis, amplified by the abrupt onset of the disease, the possibility of performing the BMT emerged for 14 donors for as a reassuring factor, while, for the other six, it seems to have functioned more as an trigger event for anxiety. What to do? If I did not do the transplant, with only the medicine he would not be good, but if I did and he died? (Male, 40 years, married). 
Often the fears and fantasies about the procedure were related to unfamiliarity with the technique, since most participants had never heard of bone marrow transplantation, as was the case for 16 of the donors. Disinformation gave rise to preconceptions and unfounded fears. I thought it was just one surgery. I thought of an operation on the spine, that I could not walk anymore... (Male, 34 years, married).

In three statements there still appeared the perception of inherent difficulties in the procedure, the restrictions imposed by this technique on the patient's life and even deaths resulting from complications of BMT, being mentioned. People after BMT survive another six months, right? But it is the chance of him living a while longer... (Female, 33 years, separated).

This ambivalence between placing trust in the possibility of a cure and considering the inevitability of a fatal outcome permeated the discourse of the donors. The potential for salvation was named as the most significant factor that had led them to position themselves favorably to carry out the BMT. When they said he needed a transplant I saw that this thing was serious; I know that many people die, but there is a chance for it to be good, right? (Female, 22 years, married). This speech also shows that the indication of the BMT functioned as a sign of the severity of the condition.

Regarding the bone marrow donation, the fact of having been the one chosen, from the family members tested, for all of the donors was accompanied by anxiety reactions. When it came to the donation, they frightened me a lot. It even gave me fever. I was terrified (Female, 33 years, separated).

All demonstrated that they assimilated and understood the basic information about the process. I will go to a surgery room, I will have a general anesthesia for the marrow to be removed by needles. After this the marrow will be treated and passed to my brother (Male, 22 years, single). Nineteen donors considered general anesthesia as a major source of anxiety. They feared the possibility of not returning again from the state induced by the anesthetic. And if when I am there sleeping, I sleep forever? (Male, 28 years, single). Fantasies emerged, in four donors, concerning the implications of the donation process, such as: the fear of taking all the blood, of transmitting personality characteristics to the recipient, and of becoming impotent after the act of donating. A very common confusion among non-professionals is the similarity between the bone marrow and spinal cord, which transpired as the fear of being paralyzed. The business that bothers me is not to walk anymore, but if it is to save my sister, I'd rather be in a wheelchair and she lives (Male, 36 years, separated).

Despite these fears, the refusal to serve as a donor was zero, with the biggest reason that justified the decision to donate the marrow being the possibility and the consequent responsibility to save the sibling's life, even in cases where family members constituted positions in a manner contrary to the donation. I'm very scared, I'm afraid. I have to think that I have children, but what can I do? It has to be me! So it will be (Female, 22 years, married).

Mentioned as motives for accepting the burden of donating were constraints caused by pressure from the family nucleus and from friends, as well as religious precepts, especially in those donors who did not present difficulties in their relationship with the patient. I thought of not donating, but what would I tell my mother? My friends also advised me: your brother needs you... then I had no escape (Male, 28 years, single).

When asked if the organ to be donated to the sibling was a kidney and not bone marrow, 18 participants said they would donate and two argued that they would make the donation if there were no threat to their life. Regarding donating marrow to a stranger, 17 expressed that they would donate, two would not donate and one would donate if it was for an acquaintance. It is very tiring, it is the kind of thing you only do for someone you love (Male, 28 years, single).

\section{Experiencing the donation of marrow}

In the interviews which occurred after the donation of bone marrow, 14 participants complained about the need to be hospitalized, especially due to the impossibility of the presence of a companion. At first, I was very nervous. I had never been hospitalized. I was very lonely. It was even difficult to get to sleep (Female, 22 years, married). Insomnia the night before the donation appeared in the accounts of 12 participants. I could not sleep, I rolled over in bed from side to side. The next day never came, I think it was the longest night of my life (Female, 31 years married).

The feelings experienced were classified by all donors as unpleasant such as: fear, nervousness, anxiety and worry. The fear of death appeared in the discourses of 11 of the 20 donors. I was afraid, afraid of dying, fear of not waking up anymore, but still I did not think about stopping (Female, 34 years, married). These unpleasant sensations, for these donors, lasted until the moment of entering the operating room. When I went down to the operating room I was feeling butterflies in my stomach, then my hand started shaking, I thought I would faint (Male, 27 years, married). 
Nineteen donors reported feeling a little pain the day after the donation. There is a little pain, some drowsiness, but at the time it did not hurt at all, the pain came after (Female, 22 years, married). However, 18 donors said that the donation was easier than they had imagined it would be. At the end of the donation I was better than I thought, I did not see or feel anything. (Male, 36 years, separated). These participants noted as factors that facilitated this process the prior contact with the team which occurred in the pre-BMT stage and in the first week of hospitalization of the sibling, as well as the support received by these professionals. I think it was easier for me because $I$ was already used to the hospital and the people here (Female, 18 years, married).

In relation to the meanings attributed to the donation, when requested, at the end of the interview, to complete the phrase: "for me, being a donor is ...", the majority (14 donors), said it was something very positive, a privilege, to have the opportunity to be able save someone's life. What I feel is happiness to have been chosen, that God allowed this of us, to be able serve someone. And to be one to be blessed (Male, 38 years, married). Three participants described it as a "normal" event, with positive and negative points. Normal. Good and bad. Good to be able to help my brother, bad because of the fear (Female, 34 years, married). Three participants said there was nothing good, that they would have preferred not to have donated the marrow. Not very good. I had to go against my husband, who did not want me to donate. I wish it had been someone else (Female, 31 years, married).

\section{Discussion}

The data obtained show that in the stage prior to the process of bone marrow donation a recurrent issue arises: the impact that the illness of the relative has on the life of the donor sibling. The diagnosis of a potentially fatal condition is a trigger for dysphoric reactions, such as "surprise" and "despair", that mobilizes the entire family unit. This is corroborated by findings in the literature, that show that the psychological impact of the diagnosis not only affects the patient, but extends to the entire family unit ${ }^{(3)}$.

Changes that occurred after the discovery of the sibling's illness were common in the reports, in particular alterations experienced in the family system. These modifications generally appeared accompanied by a dysphoric emotional tone, but also receive a positive meaning as an opportunity for re-approximation of family members. Such a movement of family reunification seems to be related to the overload of feelings mobilized by a diagnosis of an onco-hematological disease that's reserved prognosis brings the fear aroused by the very concrete possibility of the loss of the relative ${ }^{(4)}$.

Allied to the illness of the sibling the fact still appears that the transplant is seen as a saving and threatening-treatment at the same time, generating an important psychological impact and emotional ambivalence in the patient and their family ${ }^{(4)}$. It is, however, an effective possibility of salvation in cases of diseases refractory to conventional treatments, often considered as the only means available to achieve a cure $^{(4)}$. That hope is what makes the donors encourage the sibling to undergo BMT.

Regarding the reaching of a decision on donating bone marrow, despite fears related to the donation process, refusal was zero. These data corroborate the findings in the literature, which indicated that the main motivations in related donation are, the fact that the subject is placed, potentially, as the savior of the life of a family member, as well as religious beliefs. Hence it is very difficult to sustain a refusal in such circumstances, despite the fear and ambivalence that mark the desire to donate bone marrow ${ }^{(14)}$. This responsibility to donate marrow and to see themselves placed with the burden of "saving the sibling", and the consequent impossibility of escape from this responsibility can become overwhelming and lead to psychological distress and symptoms of anxiety in the related bone marrow donor ${ }^{(5)}$. In this study, the donors reported the experience of unpleasant feelings such as fear, nervousness, anxiety and worry.

The results obtained conform to what was expected according to the literature, which states that related bone marrow donors present negative emotional reactions, resulting from the stress triggered by the donation and its psychological implications ${ }^{(6)}$. According to the data collected during the interviews, this situation of stress interferes in all spheres of life of the siblingdonor relationship. Indeed, the participants reported family and professional difficulties, which increased their vulnerability to psychosocial stressors.

Regarding the difficulties experienced in the family relationships, the discourse of donors evidenced the conflict that arises between the family of origin, which encourages, and to some extent, creates pressure for the donation to take place, and the constituted family that often actively opposes such an act, however meritorious it may be. Evidence of family conflicts triggered by the opportunity to donate bone marrow is also a finding of the literature ${ }^{(4)}$. 
As the results indicate, the framework of emotional tension and stress lasts until just before donation, and at that time, reassuring factors appear such as the donor's prior contact with the hospital environment and the fact of being hospitalized in the BMTU, where they receive the support of the multidisciplinary team.

\section{Final considerations}

This study demonstrated that bone marrow donation entails diverse psychological implications for the sibling donor, who experiences stressful events such as the sibling's illness, the treatment decision, the discovery of compatibility and the responsibility of being the donor. Given these findings it is important that the team devise strategies for intervention, with both educative as well as psychotherapeutic characteristics, which permit the specific needs of these individuals to be met in each stage experienced, so as to promote emotional expression and elaboration of the feelings aroused. Such care directed to the donor should extend throughout the period from the discovery of being a donor until the end of the treatment of their sibling.

\section{References}

1. Machado VOC, Leal KPH, Moscatello ELM, organizadores. Transplante de medula óssea: abordagem multiprofissional. São Paulo: Lemar; 2009. 346 p.

2. Matsubara TC, Carvalho EC, Canini SRMS, Sawada NO. A crise familiar no contexto do Transplante de Medula Óssea (TMO): uma revisão integrativa. Rev. Latino-Am. Enfermagem. 2007; 15(4):665-70.

3. Oliveira EA, Voltarelli JC, Santos MA, Mastropietro AP. Intervenção junto à família do paciente com alto risco de morte. Medicina, Ribeirão Preto 2005; 38(1):63-8.

4. Oliveira EA, Santos MA, Mastropietro AP, Voltarelli JC. Repercussões psicológicas do transplante de medula óssea no doador relacionado. Psicol Ciênc Prof. 2007; 27(3):430-45.

5. Shama WI. The experience and preparation of pediatric sibling bone marrow donors. Soc Work Health Care1998; 27(1):89-95. 6. Chang G, McGarigle C, Spitzer TR, McAfee SL, Harris F, Piercy $\mathrm{K}$, et al. A comparison of related and unrelated marrows donors. Psychosom Med. 1998; 60(2):163-7.

7. Chang G, Mcgarigle C, Koby D, Antin J. Symptoms of pain and depression in related marrow donors: chances after transplant. Psychosomatics 2003; 44(1):59-64.

8. Nishimori M, Yamada Y, Hoshi K, Akiyama Y, Hoshi Y, Morishima $Y$, et al. Health-related quality of life of unrelated bone marrow donors in Japan. Blood 2002; 99(6):1995-2001.

9. Wolcott DL, Wellisch DK, Fawzy FI, Landsverk J. Psychological adjustment of adult bone marrow transplant donors whose recipient survivors. Transplant. 1986; 41(4):484-8.
10. Bredeson C, Leger C, Couban S, Simpson D, Huebsch L, Walker I, et al. An evaluation of the donor experience in the Canadian multicenter randomized trial of bone marrow versus periphel blood allografting. Biol Blood Marrow Transplant. 2004; 10(6):405-14.

11. Fortaneir C, Kuentz M, Sutton L, Michael M, MacQuart-Monlin $G$, Faucher $C$, et al. Healthy sibling donor anxiety and pain during bone marrow or peripheral blood stem cell harvesting for allogenic transplantation: results of a randomized study. Bone Marrow Transplant. 2002; 29(2):145-9.

12. Christopher KA. The experience of donating bone marrow to a relative. Oncol Nurs Forum 2000; 27(1):693-700.

13. Guimarães FAB, Santos MA, Oliveira EA. Quality of life of patients with autoimmune diseases submitted to bone marrow transplantation: a longitudinal study. Rev. Latino-Am. Enfermagem. 2008; 16(5):856-63.

14. Lemes MMD, Bastos MAR. The maintenance care of potential organ donors: ethnographic study on the experience of a nursing team. Rev. Latino-Am. Enfermagem. 2007; 15(5):986-91.

15. Moraes EL, Massarollo MCKB. Family refusal to donate organs and tissue for transplantation. Rev. Latino-Am. Enfermagem. 2008; 16(3):458-64.

16. Brewer J, Hunter, A. Multimethod research: a synthesis of styles. Califórnia: Sage Newbury Park; 1989. 216 p.

17. Triviños ANS. Introdução à pesquisa em ciências sociais: a pesquisa qualitativa em educação. São Paulo: Atlas; 1992. 176 p. 18. Bardin L. Análise de conteúdo. Lisboa: Edições 70; 2002. $223 \mathrm{p}$.

Received: Jun. $29^{\text {th }} 2009$

Accepted: Nov. 16 2009 